\title{
ANALYSIS OF DIFFICULTY IN DESIGNING LEARNING SCIENCE IN ELEMENTARY SCHOOL
}

\author{
Ramdhan Witarsa ${ }^{1}$, Asep Solihat ${ }^{2}$, Dini Nurhasanah ${ }^{3}$, Nia Karlina ${ }^{4}$ \\ ${ }^{1}$ IKIP Siliwangi \\ ${ }^{2}$ SDN Baros Mandiri 2 \\ ${ }^{3}$ SDN Mekar Rayahu 1 \\ ${ }^{4}$ SDN Babakan Loa \\ ${ }^{1}$ witadan44@gmail.com, ${ }^{2}$ asepsolihat1982@gmail.com, \\ ${ }^{3}$ syahnafri1984@gmail.com, ${ }^{4}$ nengniakarlina@gmail.com
}

\begin{abstract}
Learning science is a learning done in Elementary School (ES). During this time, science learning is still felt difficult by most teachers and prospective ES teachers. These difficulties include difficulty in designing learning. These difficulties affect the readiness and ability of teachers in implementing learning in the classroom. The purpose of this study is to analyze the difficulties experienced by the PGSD study program in terms of planning science learning in ES. The research method used is descriptive quantitative research method. The population of this research is the students of PGSD IKIP Siliwangi who take the course of Learning Planning in ES as many as 50 students. The sampling method used purposive sampling technique, which is apprentice applicant 1 who get the learning planning in ES as much as 25 students. The data collected were questionnaire and data analysis using mode. The results showed that the sequence of the most difficult steps to the easiest in planning science teacher candidate elementary as follows: 1). Mapping SK / KD and indicators; 2). Determining indicators; 3). Determining effective weeks; 4). Arrange syllabus; 5). Establish an assessment; 6). Preparing RPP; 7). Prepare teaching materials.
\end{abstract}

Keywords: Analysis of difficulties, planning of science learning, elementary school.

\section{INTRODUCTION}

Regulation of the Minister of National Education Number 22 Year 2006 states that science learning in elementary school (ES) is implemented through an integrative scientific approach. Based on the government mandate mentioned above, education in elementary school must be implemented with integrative science-based learning. Integrative scientific learning is a learning that is carried out in elementary school especially in science subjects. Students in elementary school according to their cognitive development level are distinguished in the lower and upper classes or the first class generally sit in the first year to three (Praseto, 2008).

Since the required Permendiknas 22 Year 2006, science learning is still felt difficult by most teachers and prospective elementary school teachers. These difficulties include difficulties in the planning of science learning, these difficulties affect the readiness and ability of teachers in implementing learning in the classroom. Unresolved complaints and 
lack of solutions will cause problems and if not resolved will cause confusion for the teacher and impact on the unfinished learning of science should be.

Based on the gap between the conditions in the field of teachers are still difficulties in science learning, the researchers considered it necessary to do research that aims to analyze the difficulties experienced by students in the study program PGSD science learning in elementary.

\section{Research Problems}

Based on this background, then the problem formulation in this research is how the difficulties experienced by students of PGSD study program in terms of science learning plan in elementary school?.

\section{Research Purposes}

The purpose of this research is to analyze the difficulties experienced by PGSD students in planning science learning in elementary school.

\section{Benefits of Research}

Benefits derived from this research is after knowing difficulties in science learning planning, lecturers can make improvements in science learning in terms of methods and strategies.

\section{Research Study}

In the implementation of science learning, it is necessary to do some things that include planning phases that include basic competence mapping activities, syllabus development, and preparation of learning implementation plans.

\section{a. Mapping of Basic Competencies}

This mapping activity is carried out to obtain a comprehensive and complete picture of the same competency standards, basic competencies and indicators and various combined and chosen learning eyes. Activities undertaken as follows:

1) Elaboration of Competency Standards and Basic Competencies into Indicators Conduct standardization activities of competency standards and basic competencies of each subject into indicators. In developing indicators need to pay attention to the following matters:

a. Indicators are developed in accordance with the characteristics of learners.

b. Indicators are developed according to the characteristics of the subjects. 
c. Formulated in operational verbs that are measurable and / or observable.

2) Setting Discussion

a. How to determine the discussion

In terms of determining the discussion can be done in two ways as follows:

The first way is to study the basic competency standards contained in each subject, followed by determining appropriate discussion. The second way is to prioritize the binding of cohesiveness, in order to determine the subject, the teacher can cooperate with the learners so that they match the interests and needs of the child.

b. The principle of determining the discussion

In the discussion of the need to consider the following principles:

- Pay attention to the immediate environment of the student.

- From the easiest to the hard.

- From simple to complex.

- From the concrete to the abstract.

- The selected topic should enable the thinking process to the students.

- The scope of the subject is tailored to the age and development of students, including their interests, needs, and abilities.

c. Identification and analysis of Competency Standards, Basic Competencies and Indicators. Identify and analyze for each Competency Standards, Basic Competencies and indicators suitable for each subject so that all competency standards, basic competencies and indicators are shared.

d. Setting Relationships

Make a discussion that is linking basic competencies and indicators with the discussion will show the relationship between discussion, basic competence and indicators of each subject. This discussion can be developed in accordance with the time allocation of each discussion.

e. Preparation of Syllabus

The results of all the processes that have been done in the previous stages are used as the basis for the preparation of the syllabus component consisting of competency standards, basic competencies, indicators, learning experiences, tools / resources, and assessment. 
f. Preparation of Learning Plans

For the purpose of teaching implementation, teachers need to develop a learning implementation plan. This lesson plan is a realization of the student learning experience that has been established in the learning syllabus. The thematic learning plan components include:

- Subject identities (the names of the subjects to be integrated, class, semester, and time/number of meeting hours allocated).

- Basic competencies and indicators to be implemented.

- The subject matter and its description that need to be studied by students in order to achieve basic competence and indicator.

- Learning strategies (concrete learning activities that students must do in interacting with learning materials and learning resources to master basic competencies and indicators, this activity is contained in the opening, core and closing activities).

- Tools and media used to facilitate the achievement of basic competence, as well as the source of materials used in thematic learning activities in accordance with the basic competencies that must be mastered.

- Assessment and follow-up (procedures and instruments to be used to assess student learning achievement and follow-up assessment results).

\section{METHOD}

\section{Types of Research}

This research is quantitative descriptive research. This means that in this study the data have been obtained will be tabulated using simple statistics of the mode or numbers that appear most at every step of science learning planning.

\section{Population and Sample Research}

The population of this study is prospective elementary school teachers or students PGSD IKIP Siliwangi force 2016 amounted to 50 students. The method of determining the sample is purposive sampling that is the 1st apprentice applicant who obtained the science learning test. This is done with the consideration of apprentice participants 1 more serious working on RPP so to know the difficulty in planning or preparation of RPP more can be done. The sample is 25 students. 


\section{Method of Collecting Data}

The data needed to uncover difficulties in science learning planning is the primary data in the form of an open questionnaire. The lattice analysis of student difficulties is referring to the steps of preparing the science learning plan as follows:

1. Determine the indicator.

2. Determining the discussion and the effective week.

3. Mapping SK / KD and indicators into the discussion.

4. Prepare a discussion of one semester.

5. Prepare the discussion relationships per discussion.

6. Prepare a discussion per discussion.

7. Develop a weekly discussion.

8. Develop a daily discussion.

9. Prepare a syllabus.

10. Develop a Lesson Plans (RPP).

11. Prepare the Teaching Materials.

12. Develop Assessment.

\section{Data Analysis Method}

The data that have been obtained is analyzed using the mode that is the most number appear in every step of science learning plan. The most common sequence is then a sequence in the difficulty of science learning.

\section{RESULTS AND DISCUSSION}

This research is a quantitative descriptive research where the data comes from questionnaire which is shown to prospective elementary school teachers who take the internship exam 1 or microteaching in PGSD IKIP Siliwangi Study Program. The sample selection is aimed at the participants of the internship exam 1 because the sample is more serious or more difficulty in preparing the specific Subject of Paedagogik (SPP) compared to the other interns.

Questionnaires compiled from the guidelines or steps of preparing the science learning plan from the National Agency for Standards of Education (BNSP) is divalidari by science learning experts from the study program PGSD IKIP Siliwangi. The result of questionnaire validation states that the questionnaire can be used to take the data of this Analysis of Difficulty in Designing Learning Science in Elementary School | 29 
research and be in good category. The results of the recapitulation of the research questionnaire indicate that the step of mapping SK, KD and indicators into the discussion is the most difficult step done by prospective elementary teachers, while the easiest step is to prepare teaching learning materials science.

Table 1

Research Results

\begin{tabular}{|c|c|c|c|c|}
\hline Planning Steps & $\begin{array}{l}\text { It's Easy to Difficult } \\
1234567891011\end{array}$ & Amount & $\%$ & HA \\
\hline Define the indicator & 55602231000 & 25 & 25 & 2 \\
\hline $\begin{array}{l}\text { Determining the effective } \\
\text { discussion and week }\end{array}$ & 13043341113 & 25 & 17 & 3 \\
\hline $\begin{array}{l}\text { Map SK, KD, and } \\
\text { indicators }\end{array}$ & 82412241000 & 25 & 33 & 1 \\
\hline Prepare a syllabus & 12221212542 & 25 & 21 & 4 \\
\hline Prepare RPP & 21114111183 & 25 & 33 & 6 \\
\hline Prepare teaching materials & 21040304109 & 25 & 38 & 7 \\
\hline Develop an assessment & 12233221620 & 25 & 25 & 5 \\
\hline
\end{tabular}

Table 1 shows the easiest results (1) maps the SK / KD and indicators into the discussion (2) determines the indicators (3) determines the effective discussion and week (4) prepares the syllabus (5) prepares the assessment (6) prepares the RPP (7) ) compile teaching materials. From the results of the study showed that $34 \%$ of primary school teachers experiencing the most difficult step in planning science learning is to map SK / KD and indicators. At the planning stage of preparing the lesson plan and preparing each teaching material is considered very difficult by $8 \%$ of elementary school teachers. While in the step of determining the discussion and the effective week, compiling syllabus and making the assessment is considered very difficult for each step of $4 \%$ of the total respondents.

Based on Tabal 1 it can be seen also that in addition to $33 \%$ of prospective teachers considered the most difficult step in science learning in elementary school is to map the Competence Standards / Basic Competencies (SK / KD) and indicators into the discussion. The information obtained from the questionnaire states that the cause of this is because the prospective teacher must adjust the indicators that can be linked with indicators that can be linked with other subject indicators in order to appear integrative. In this step required imagination or high imagination of elementary school teachers in imagining the lesson to be done. 
This mapping exercise is conducted to obtain a comprehensive and complete picture of all competency standards, basic competencies and indicators of the various subjects combined in selected science subjects. Activities undertaken among others (1) Identification and analysis of Competency Standards that is to identify and analyze for each competence standard suitable for each discussion so that all standard of competence is divided (2) Identification and analysis of Basic Competence is to identify and analysis for each basic competence suitable for every discussion (3) Indicator identification and analysis is to identify and analyze each suitable indicator for each discussion so that all indicators are divisible (BNSP, 2006).

Some prospective teachers find it difficult to adjust one SK to another while other prospective teachers have difficulty adjusting the subject with SK / KD. When mapping SK / $\mathrm{KD}$ and discussion into indicators, prospective teachers should predict the learning path to be implemented. In addition, how to connect between subjects should have been prepared or predicted earlier so that learning can be done maximally and not be a science-based learning course only.

As many as $21 \%$ of prospective teachers consider the second difficult thing is to determine their own indicators. This is because prospective teachers are still confused by using the Operational Verbs (KKO) and the difficulty of sorting from the lowest to the hardest especially when required to develop indicators for processes, products and characters. In addition, prospective teachers are still confused to sort KKO based on the characteristics of the students. In BNSP (2006), there are two points in preparing indicators: (1) indicators should be tailored to the needs and characteristics of learners and the characteristics of subjects and (2) indicators formulated in operational verbs that can be measured and observed by students or teachers.

The first step of the development of indicators is to analyze the level of competence in SK and KD. This is necessary to meet the minimum demands of competence that are made as a national standard. Schools can develop indicators beyond these minimum standards (BNSP, 2006). Based on the questionnaire filled with prospective elementary teachers, their difficulty in preparing indicators is at number two, namely formulating the $\mathrm{KKO}$ in accordance with the characteristics of students and the characteristics of subjects.

The level of competence can be seen through the operational verbs used in SK and KD. The level of competence can be classified in three parts, namely the level of knowledge, process level, and application level. Verbs at the knowledge level are lower than the process 
and implementation level. The application level is the highest required level of competence (BNSP, 2006). Based on the questionnaire, prospective teachers have difficulty in setting up an affective domain indicator, Their difficulty lies in sequencing the affective domain from the simplest to the complex or from the easy to the difficult.

The most difficult thing when the science learning plan in elementary school is to determine the discussion because it must determine the discussion and the week effective. A total of $17 \%$ of prospective teachers have difficulty determining the discussion that binds the integration between SK / KD and the indicators that have been made. Some prospective teachers have difficulty on the demands of variations of the discussion to appeal to students. The difficulty in determining the subject matter experienced by prospective elementary teachers is the closest to the students. In addition, the determination of themes from easy to difficult or simple to complex for students is also a constraint of their own for the prospective teacher.

The difficulty in crafting an effective week lies in the calculation of the effective week per discussion. This is because the prospective elementary school teachers should predict the complexity, the carrying capacity of the students for learning in one discussion thoroughly in accordance with the specified time allocation. Thus, although Permendiknas Number 22 Year 2006 has given the effective week reference in one year is 34-38 weeks effective, but to break down into one semester or discussion, prospective teachers still have difficulty.

The fourth step that is considered difficult is to arrange the discussion relationships within one semester. As many as $21 \%$ of prospective teachers said that the difficulty is to integrate SK / KD and indicators of all subjects in one semester is not easy because sometimes it is considered less fit is included in the discussion. Even some of the prospective teachers feel that in incorporating the indicator on SK / KD impressed imposed because it does not have a picture of learning to be done. Another difficulty faced is the technical problem of writing is how to load dozens of indicators per subject put together in one semester. To do this requires a separate writing technique.

A total of $17 \%$ of prospective teachers consider that composing weekly discussions is the fifth most difficult step in preparing the SSP. This is because they or the prospective teacher is difficult to determine a suitable subject in a week. According to them, it is quite difficult to divide the discussion per semester into the discussion per week because it must determine the effective week first. At the time of calculating the effective week for one semester must be adjusted with Permendiknas Number 22 Year 2006 on Content standard 32 | Analysis of Difficulty in Designing Learning Science in Elementary School 
that is effective week for SD is 34-38 weeks effective. The educational calendar should be the reference in determining the effective week.

Preparing the syllabus is the sixth difficulty of the prospective elementary teacher in planning science lessons in elementary school. As many as $21 \%$ of prospective teachers stated so. This is because many aspects that need to be considered include learning activities. Learning activities are the most difficult in designing the syllabus because it adapts to indicators that have been made. Statement of prospective elementary teachers in this study is in line with the results of research Gularso (2010) which states that the difficulties experienced by elementary school teachers in science learning is the preparation of learning activities on the syllabus.

Seventh difficulty in science teaching plan of elementary school teacher is determining the discussion of discussion per discussion. As many as $25 \%$ of potential teachers experience difficulties due to difficulties in first determining large discussion to combine the small themes of one semester discussion. As in the theory of discussion of BNSP (2006) that the discussion should be made from the easiest to the most difficult, from concrete to complex and the discussion must be in accordance with the needs and characteristics of the students of the elementary school concerned.

Planning steps that are considered difficult next is to make an assessment. Table 1 shows that $25 \%$ of prospective teachers give the eighth order for this step. They argue that the difficulty of judgment depends on the predetermined indicator in the first step. Assessment in science learning is done per subject because it is assessed is the competence of each indicator per subject so scientific is an approach in the course of learning, but the assessment remains per subject in accordance with the competencies that have been formulated at the time of preparing indicators of learning. Some elementary school teachers have difficulty in preparing rubrics for affective and psychomotor assessments.

The ninth difficulty sequence for the analysis of the difficulties of science learning planning step is to prepare the Lesson Plans (RPP). A total of 33\% of prospective teachers stated so. The reason they stated that the preparation of RPP is not too difficult for them is the RPP stay down and develop from the syllabus. RPP development lies in more detailed learning activities than syllabus. Difficulties experienced by prospective teachers is to share the activities of teachers and activities undertaken by students. In addition, exploration, elaboration and confidence are also the focus of RPP work. 
The last difficulty or the easiest one in the planning step of science learning is the preparation of teaching materials. About $38 \%$ of prospective teachers choose teaching materials as the easiest step (Table 1). This is because the teaching materials are available from both stores and science books that circulate in the community. Some elementary school teachers develop existing teaching materials with additional knowledge available on the internet for more contextual teaching materials.

\section{CONCLUSION}

The sequence of the most difficult steps to the easiest in planning the science of the prospective primary teacher is as follows: (1) map the SK / KD and indicators into the discussion (2) determine the indicator (3) determine the discussion and the effective week (4) arrange the syllabus (5) (6) preparing RPP (7) preparing teaching materials. Suggestions for LPTKs are to improve coaching and coaching on the difficulty of sequences 1 to 3 where prospective teachers are still a lot of confused and those three things are at the heart of the problem. This step is domino so that if the first step is wrong then the next step is also wrong. Suggestions for further researchers are samples taken more so that the results are closer to the truth and can be generalized.

\section{ACKNOWLEDGMENTS}

The chief researcher and the members would like to thank the Team and ES for their good cooperation during the research. The institution's trust will continue to be maintained and we will continue to develop in future studies.

\section{REFERENCES}

Badan Standar Nasional Pendidikan. (2006). Model Pembelajaran Tematik Kelas Awal SD, Departemen Pendidikan Nasional: Jakarta.

Dhiniaty, G. (2010). Pendidikan Kemampuan Guru Standar Sekolah Dasar Kelas I, II, dan III dalam Pembelajaran Menggunakan Pendekatan Tematik di Kecamatan Kasihan, Kabupaten, Banten Provinsi Daerah Istimewa Yogyakarta. Jurnal Simbiosis, Prodi Pendidikan Biologi Jurusan PMIPA FKIP Universitas Patimura Ambon Vol. 7 No. 1 April 2010 No. ISSN 1829-5452 Hal 187-193.

Dhiniaty, G. (2011). Potret Pelaksanaan Pembelajaran Tematik Di Sekolah Dasar Kabupaten Bantul Daerah Istimewa Yogyakarta. Jurnal Pendidikan dan Humaniora "Kompetensi" FKIP UNIBA Vol. 2 No. 1, Juli 2011 No. ISSN 2087-0485 hal 19-29.

Peraturan Menteri. (2006). Peraturan Menteri Nomor 6 Tahun 2007 Tentang Kurikulum Tingkat Satuan Pendidikan.

Peraturan Menteri. (2006). Peraturan Menteri Nomor 22 Tahun 2006 Tentang Standar Isi untuk Pendidikan Dasar dan Menengah .

Peraturan Menteri. (2006). Peraturan Menteri Nomor 23 Tahun 2006 Tentang Standar Kompetensi Kelulusani untuk Pendidikan Dasar dan Menengah.

Sugiyono. (2007). Metode Penelitian Pendidikan, Pendekatan Kuantitatif dan $R \& D$, Penerbit : Alfabeta, Bandung.

34 | Analysis of Difficulty in Designing Learning Science in Elementary School 